\title{
PELATIHAN DEBAT DALAM BAHASA INGGRIS UNTUK SISWA SMA PGRI 6 BANJARMASIN
}

\author{
Nurfitriah ${ }^{I}$, Muhammad Amril Asy'ari ${ }^{2}$, Ria Adriyati ${ }^{3,}$ Suwaji $^{4}$ \\ Prodi Teknik Pertambangan Jurusan Teknik Sipil Politeknik Negeri Banjarmasin ${ }^{1,2}$ \\ Prodi Teknik Sipil Jurusan Teknik Sipil Politeknik Negeri Banjarmasin ${ }^{3,4}$ \\ nurfitriah@poliban.ac.id ${ }^{1}$ \\ ria_adriyati@ymail.com ${ }^{3}$
}

\begin{abstract}
PGRI 6 High School (SMA) Banjarmasin has common problems related to the availability of human resources and competencies to be able to manage extracurricular activities in English, especially for debating, hence students from this school have never participated in related competition activities at the local or national level. The English teaching teachers at this school are highly motivated to send representatives of students to take part in the debate competition but they have difficulties to begin preparations for this debate competition. They do not know how the recruitment and selection process for students to debate, nor have the expertise and knowledge about debate and there is no budget for the whole series of student debating activities. Banjarmasin State Polytechnic as one of the state universities in South Kalimantan which already has a well-known name in the English language debate level at local, regional and national level offers a solution to the problems of extracurricular activities in the form of debate training in English for high school students of PGRI 6 Banjarmasin. This community service activity aims to initiate extracurricular activities and improve the ability to debate in English for students of PGRI 5 Banjarmasin High School. The targeted output is the formation of a forum for partner school students to improve their English skills through debate and the selection of student representatives to participate in the debate competition. The teachers of English are expected to have knowledge of managing English extracurricular debate activities after joining the training.
\end{abstract}

Keywords: extracurricular, debate, English

\begin{abstract}
ABSTRAK
Sekolah Menengah Atas (SMA) PGRI 6 Banjarmasin memiliki permasalahan umum terkait ketersediaan sumber daya manusia dan kompetensi untuk bisa mengelola kegiatan ekstrakurikuler Bahasa Inggris terutama debat sehingga siswa dari sekolah ini belum pernah mengikuti kegiatan kompetisi terkait baik di tingkat local maupun nasional. Para guru pengajar Bahasa Inggris di sekolah ini memiliki motivasi yang tinggi untuk mengirim perwakilan siswa untuk mengikuti lomba debat akan tetapi mereka mengalami kesulitan untuk memulai persiapan untuk lomba debat ini. Mereka tidak tahu bagaimana proses rekrutmen dan seleksi siswa untuk debat, tidak memiliki keahlian dan pengetahuan tentang debat dan belum ada anggaran untuk seluruh rangkaian proses kegiatan debat siswa ini. Politeknik Negeri Banjarmasin sebagai salah satu perguruan tinggi negeri di Kalimantan Selatan yang sudah memiliki nama yang cukup dikenal di kalangan debat Bahasa Inggris tingkat perguruan tinggi baik tingkat local, regional maupun nasional menawarkan solusi terhadap permasalahan kegiatan ekstrakurikuler
\end{abstract}


tersebut berupa pelatihan debat dalam Bahasa Inggris untuk siswa SMA PGRI 6 Banjarmasin. Kegiatan pengabdian kepada masyarakat ini bertujuan untuk menginisiasi kegiatan ekstrakurikuler debat dan meningkatkan kemampuan debat dalam bahasa Inggris untuk siswa SMA PGRI 5 Banjarmasin. Luaran yang ditargetkan adalah terbentuknya wadah bagi siswa sekolah mitra untuk meningkatkan kemampuan bahasa Inggris mereka melalui debat dan terpilihnya perwakilan siswa untuk mengikuti lomba debat. Para guru pengajar bahasa Ingggris setelah pelatihan ini diharapkan akan memiliki pengetahuan pengelolaan kegiatan ekstrakurikuler debat bahasa Inggris.

Kata kunci : ekstra kurikuler, debat, Bahasa Inggris.

\section{PENDAHULUAN}

Pembelajaran bahasa Inggris di sekolah-sekolah masih menjadi prioritas untuk dikembangkan, karena bahasa Inggris merupakan bahasa internasional yang paling banyak dipakai. Menguasai bahasa Inggris bisa membuka banyak peluang baik itu didunia pendidikan maupun di dunia kerja, terutama untuk menghadapi diberlakukannya Masyarakat Ekonomi Asia. Menyadari pentingnya peran bahasa Inggris, ada banyak sekolah, terutama tingkat SMA yang menambah jam pelajaran bahasa Inggris untuk memastikan bahwa siswa tersebut dapat menguasai bahasa Inggris lebih baik.

Menurut pengamatan di beberapa sekolah khsusnya di tingkat sekolah menengah atas di banajrmasin mempunyai kegiatan extrakurikuler bahasa Inggris dimana sekolah-sekolah tersebut mengundang guru atau instruktur dari luar untuk mengisi kegiatan ekstrakurikular tersebut. Beberapa kegiatan yang dilakukan dalam ekstrakurikular tersebut bisa berupa praktek berbicara (conversation), story telling, latihan debat (debate), dan pidato (speech). Kegiatan- kegiatan tersebut dipilih karena keterampilan berbicara dianggap bisa menjadi tolak ukur keberhasilan belajar bahasa Inggris. Disamping alasan tersebut, banyaknya lomba story- telling, debate, dan speech tingkat SMA dan sederajat menjadi ajang pembuktian prestasi siswa dalam penguasaan bahasa Inggris. Sehingga, beberapa sekolah memutuskan untuk melatih siswa untuk ketrampilan-ketrampilan tersebut. Selain untuk meningkatkan kemampuan berbahasa Inggris, sekaligus untuk mempersiapkan siswa untuk mengikuti lomba-lomba yang bisa meningkatkan reputasi sekolah apabila siswa tersebut memenangkan lomba.

Salah satu lomba yang diadakan setiap tahun yang diadakan oleh Kementerian Pendidikan Nasional baik di tingkat regional maupun nasional adalah National School Debate Contest (NSDC) yang merupakan lomba pidato yang diikuti oleh siswa-siswa SMA dan sederajat.

Dari lomba tersebut diketahui bahwa peserta lomba lebih di dominasi oleh siswa dari sekolah-sekolah favorit, selain itu kemampuan peserta lomba juga dirasa perlu ditingkatkan. Kemampuan debat (debate) dalam bahasa Inggris ini penting dimiliki oleh siswa, tidak hanya untuk mengikuti lomba tetapi bisa juga untuk meningkatkan rasa percaya diri dan kemampuan berfikir kritis siswa untuk 
menggunakan bahasa Inggris di depan umum. Debate dipercaya bisa memberikan kesempatan kepada siswa untuk berbicara dalam bahasa Inggris, berlatih mengemukakan pendapat didepan umum, dan melatih kepercayaan diri siswa untuk berbicara bahasa Inggris. Kompetisi debat bertujuan untuk memperluas wawasan peserta didik SMA agar terbiasa berpikir kreatif dan analitis, mampu bersaing secara kompetitif, berkomunikasi secara efektif, dan menyampaikan argumentasi di depan publik dengan Bahasa Inggris yang efektif, melatih peserta didik untuk menyampaikan pendapat dengan sistematis, dapat berpikir kritis kreatif analitis dan konstruktif, serta bersikap sportif dan membekali peserta didik sebagai anggota masyarakat yang potensial dengan wawasan pengetahuan dan kemampuan berkomunikasi dengan baik. Bila dilatih dengan benar, berdebat (debate) dengan bahasa Inggris ini bisa dijadiakan media pembelajaran yang efektif untuk meningkatkan kemampuan bahasa Inggris siswa SMA.

Beberapa sekolah mengadakan pelatihan debate ini dalam kegiatan ekstrakurikuler. Akan tetapi, dalam pelaksanaan extrakurikuler tersebut ada beberapa kendala yang dihadapi oleh sekolah, seperti, kurangnya sumber daya manusia (SDM) untuk menangani kegiatan tersebut. Selain itu, sumber daya manusia yang ada kurang memenuhi standar kualifikasi untuk memfasilitasi kegiatan ekstrakurikuler. Apabila bisa menemukan sumber daya manusia dengan kualifikasi yang baik, sering kali sekolah tidak punya cukup dana untuk membiayai instruktur tersebut. Selain itu, kegiatan ekstrakurikuler ini juga kurang peminatnya, disinyalir karena kurang menariknya kegiatan tersebut. Dikarenakan beberapa permasalahan diatas, pihak sekolah melaporkan bahwa kegiatan ekstrakurikuler tersebut tidak berjalan dengan baik sehingga tujuan kegiatan untuk meningkatkan kemampuan bahasa Inggris siswa tidak tercapai. Salah satu sekolah menengah atas yang mengalami kesulitan yang diuraikan di atas adalah Sekolah Menengah Atas (SMA) PGRI 5 Banjarmasin. Selain memiliki permasalahan umum di atas sekolah ini bahkan lebih parah lagi permasalahannya karena mereka bahkan belum pernah mengikuti lomba debat yang dimaksud karena minimnya informasi dan pengetahuan yang dimiliki oleh para pengajar Bahasa Inggrisnya dan keterbatasan dana. Para guru pengajar Bahasa Inggris mengakui ingin sekali mengirim perwakilan siswa untuk mengikuti lomba debat akan tetapi mereka mengalami kesulitan untuk memulai persiapan untuk lomba debat ini. Mereka tidak tahu bagaimana proses rekrutmen dan seleksi siswa untuk debat, tidak memiliki keahlian dan penegtahuan tentang debat dan belum ada anggaran untuk seluruh rangkaian proses kegiatan debat siswa ini. Oleh karena itu, perlu dicari solusi terhadap kegiatan ekstrakurikuler tersebut agar pelaksanaannya bisa efektif dan tujuan pelaksanaan bisa dicapai.

Politeknik Negeri Banjarmasin sebagai salah satu perguruan tinggi negeri di Kalimantan Selatan sudah memiliki nama yang cukup dikenal di kalangan debat Bahasa Inggris tingkat perguruan tinggi baik tingkat local, regional maupun nasional. Kegiatan latihan maupun lomba Bahasa Inggris termasuk untuk debat para mahasiswa Poliban diwadahi oleh Poliban English Community (Policy) yang beranggotakan para mahasiswa yang aktif dalam upaya meningkatkan 
kemampuan Bahasa Inggris mereka. Para debater Poliban sudah banyak menorehkan prestasi dalam berbagai lomba. Melihat besarnya potensi para debater Poliban dan untuk meningkatkan lagi keterampilan mereka dan melatih jiwa social maka dosen pengusul akan mengadakan pelatihan debat dalam Bahasa Inggris untuk siswa SMA PGRI 5 Banajrmasin. Kegiatan pengabdian kepada masyarakat dalam proposal ini bertujuan untuk menginisiasi kegiatan ekstrakurikuler debat dan meningkatkan kemampuan debat dalam bahasa Inggris untuk siswa SMA PGRI 5 Banjarmasin.

Adapun beberapa permasaahan mitra yang kami dapatkan adalah sebagai berikut: (1) belum adanya kegiatan ekstrakurikuler untuk melatih kemampuan mahasiswa debat dalam bahasa Inggris karena minimnya informasi dan kemampuan para staf pengajar Bahasa Inggris untuk kegiatan debat Bahasa Inggris, (2) minimnya SDM yang mampu memberikan pelatihan debate dalam bahasa Inggris, terutama untuk penggunaan istilah/bahasa formal dalam debate bahasa Inggris dan (3) belum adanya anggaran untuk memulai pelatihan debate dalam bahasa Inggris.

Luaran yang ditargetkan adalah terbentuknya wadah bagi siswa sekolah mitra untuk meningkatkan kemampuan bahasa Inggris mereka melalui debat dan terpilihnya perwakilan siswa untuk mengikuti lomba debat. Para guru pengajar bahasa Ingggris setelah pelatihan ini diharapkan akan memiliki pengetahuan pengelolaan kegiatan ekstrakurikuler debat bahasa Inggris.

\section{METODE KEGIATAN DAN SOLUSI}

Kegiatan Pengabdian kepada masyarakat dengan judul Pelatihan Debat dalam Bahasa Inggris untuk Siswa SMA PGRI 6 Banjarmasin dilaksanakan di SMA PGRI 6 Banjarmasin yang beralamat di Jl. Belitung Darat Simp. Kuin Selatan Komp. Antaluddin RT.19 No. 26 Banjarmasin, Kalimantan Selatan 70124. Kegiatan ini diikuti oleh siswa SMA PGRI 6 Banjarmasin yang tertarik ikut pelatihan dan didukung oleh mahasiswa debater anggota Policy.

Adapun tahapan pelaksanaan pengabdian berupa pelatihan debat dalam Bahasa Inggris adalah sebagai berikut: (a) Sosialiasi program pelatihan debat dalam Bahasa Inggris kepada mahasiswa anggota Policy yang akan terlibat dalam program PkM pelatihan debat Bahasa Inggris, (b) penentuan jadwal pelatihan ke target, (c) pembekalan mahasiswa yang akan membantu pelaksanaan program PkM, (d) pelaksanaan program pelatihan debat dalam Bahasa Inggris dan (e) pelaporan hasil kegiatan.

Solusi yang ditawarkan untuk mengatasi pemasalahan mitra adalah sebagai berikut: (1) belum adanya kegiatan ekstrakurikuler untuk melatih kemampuan mahasiswa debat dalam bahasa Inggris karena minimnya informasi dan kemampuan para staf pengajar Bahasa Inggris untuk kegiatan debat Bahasa Inggris akan diselesaikan dengan mendesain sebuah program pelatihan debat dalam bahasa Inggris dari proses rekrutmen sampai seleksi perwakilan siswa untuk mengikuti lomba. Pelatihan dirancang semenarik mungkin dengan 
melibatkan berbagai macam kegiatan seperti games, dan meaningful practices dengan pendekatan student centered learning, (2) masalah kurangnya SDM yang mampu memberikan pelatihan debate, akan dipecahkan melalui memberikan pelatihan kepada mahasiswa Poliban anggota Poliban English Community (Policy) untuk memberikan pelatihan kepada siswa-siswa di sekolah mitra dan (3) permasalahan tentang anggaran dengan sendirinya akan terbantu dengan kegiatan pengabdian yang dilakukan. Selain itu dengan adanya wacana pembentukan wadah untuk kegiatan debat siswa ini diharapkan siswa akan bisa berlatih dengan dana yang minim dengan bekerjasama dengan para mahasiswa debater.

Luaran yang diharapkan dari solusi yang ditawarkan adalah terbentuknya wadah bagi siswa sekolah mitra untuk meningkatkan kemampuan bahasa Inggris mereka melalui debat dan terpilihnya perwakilan siswa untuk mengikuti lomba debat. Para guru pengajar bahasa Ingggris setelah pelatihan ini diharapkan akan memiliki pengetahuan pengelolaan kegiatan ekstrakurikuler debat bahasa Inggris.

\section{HASIL DAN PEMBAHASAN}

Pelatihan dilaksanakan pada bulan September-Oktober 2018 sebanyak 8 (delapan) kali pertemuan. Pelatihan debat dilaksanakan setiap hari Sabtu dan diikuti oleh 15 (lima belas) orang siswa kelas XII dari Jurusan IPA dan IPS. Pelatihan dirancang sedemikian rupa untuk bisa memotivasi para peserta. Pertemuan pertama diisi dengan perkenalan tim pelaksana dan Policy. Pertemuan kedua berisikan materi pengenalan tentang system debat. Pertemuan ketiga dan selanjutnya merupakan latihan debat yang dibimbing oleh para mahasiswa Policy. Setiap pertemuan selalu diisi dengan berbagai games untuk meningkatkan kemampuan berbahasa Inggris peserta. Minimal tiga kegiatan permainan atau games diberikan untuk setiap pertemuan sebagai selingan dari materi yang diberikan. Selain untuk keperluan memotivasi peserta games yang diberikan juga dipilih untuk bisa mendiagnosa kemampuan berbahasa Inggris mereka.

Dari hasil kegiatan games ini diketahui gambaran kemampuan Bahasa Inggris peserta. Sebagian siswa yang mengikuti pelatihan memiliki kemampuan Bahasa Inggris tingkat beginner atau pemula seperti yang telah diinformasikan oleh pengajar Bahasa Inggris mereka kepada tim. Meskipun peserta masih berada di level pemula akan tetapi berkat ketekunan mereka berlatih intensif selama pelatihan terlihat kemajuan yang cukup menggembirakan. Di akhir pelatihan pengetahuan mereka tentang debat sudah meningkat. Para peserta dan juga staf pengajar Bahasa Inggris mereka menyatakan bahwa apa yang mereka terima selama pelatihan merupakan hal yang abru dan bermanfaat untuk meningkatkanpengetahuan dan kemampuan debat mereka.

\section{KESIMPULAN}

Secara umum kegiatan pelatihan debat dalam Bahasa Inggris untuk siswa SMA PGRI 6 Banjarmasin berjalan lancer dan berhasil mencapai target yang diinginkan. Staf pengajar Bahasa Inggris sekolah mitra menyatakan bahwa 
mereka telah mendapatkan gambaran tentang bagaimana mengelola kegiatan ekstra kurikuler untuk debat dan memiliki pengetahuan yang cukup untuk memulai dan meneruskan kegiatan ini. Sedikit kekurnagan dari pelatihan ini terkait dengan pemilihan peserta. Siswa yang ditawarkan untuk ikut kegiatan berasal dari kelas XII yang artinya mereka sudah berada di tahun terakhir studi mereka di sekolah sehingga dikhawatirkan mereka tidak memiliki waktu yang cukup untuk meregenerasi atau mengkader rekan-rekan mereka untuk kelanjutan program, sehingga untuk ke depannya kegiatan sejenis agar mempertimbangkan hal ini.

\section{UCAPAN TERIMA KASIH}

Ucapan terima kasih yang sebesar-besarnya kepada seluruh pihak yang telah membantu terlaksananya pengabdian ini dari tahap awal pengusulan sampai penyelesaian laporan terutama Kepala Sekolah dan dewan guru sekolah mitra SMA PGRI 6 Banjarmasin khususnya Ibu Asmah, S.Pd selaku pengajar Bahasa Inggris serta para siswa luar biasa yang menjadi peserta pengabdian ini. Penulis juga mengucapkan terima kasih tak terhingga bagi Unit P3M Politeknik Negeri Banjarmasin yang telah memungkinkan terlaksananya kegiatan ini melalui pendanaan DIPA Poliban.

\section{DAFTAR PUSTAKA}

Brewster, J., Ellis, G., \& Girard, D.,(2002). The primary English teacher's guide. England: Pearson plc.

Ward, H., \& Roden, J. (Eds.). (2016). Teaching science in the primary classroom. Sage.

Mulyasa, E. (2002). Kurikulum Berbasis Kompetensi Konsep, Karakteristik dan Implementasi. Bandung, Rosdakarya.

Sugiyono. (2002). Teori Pendidikan Praktis Bandung: Alfabeta. 